\title{
Location of S1 Nuclease-Cleavage Sites on Circular, Superhelical DNAs between Polyoma Virus and Simian Virus 40
}

\author{
Kazuo SHISHIDo \\ Department of Microbiology, The Institute of Physical and Chemical Research, \\ Wako-shi, Saitama 351, Japan
}

Received December 26, 1978

\begin{abstract}
Physical maps of the S1 nuclease-cleavage sites on double-stranded covalently closed, circular, superhelical DNAs of polyoma virus and simian virus 40 (SV 40) were constructed by the following technique: Polyoma and SV 40 DNAs were digested under defined conditions ( $30 \mathrm{~mm}$ sodium acetate buffer $(\mathrm{pH} 5.0), 60 \mathrm{mM} \mathrm{NaCl}$ at $37^{\circ} \mathrm{C}$ ) with $\mathrm{S} 1$ nuclease in the presence of $\mathrm{Mn}^{2+}$ to generate unit length linear duplex molecules. Then, the linear DNAs were digested with Eco RI and Bam NI restriction endonucleases and size of the resulting DNA fragments were analyzed by agarose gel electrophoresis. Cleavage of those DNAs with S1 is more specific in the presence of $\mathrm{Mn}^{2+}$ than $\mathrm{Zn}^{2+}$ since discrete DNA bands can be obtained after electrophoresis in agarose gels. With $\mathrm{Zn}^{2+}$ a well known activator of the enzyme, S1 cleaves these DNAs within certain regions rather than at specific sites. With $\mathrm{Mn}^{2+}$ as activator S1 cleaves polyoma DNA at seven sites: map coordinate $0.11,0.21,0.30,0.44,0.56$, 0.82 and 0.92 (fractional DNA lengths clockwise from the single $E c o$ RI cleavage site (zero position)). SV 40 DNA is cleaved by $\mathrm{S} 1$ under these conditions at map coordinate 0.15 , $0.28,0.38,0.39,0.44,0.56,0.89$ and 0.98 (also defined as fractional DNA lengths clockwise from SV 40's single Eco RI cleavage site (zero position)).

Map position 0.21 on polyoma DNA and 0.15 on SV 40 DNA are at or close to the termination site for DNA replication and the $3^{\prime}$ ends of early and late mRNAs. Map positions $0.82,0.92$ and 0.11 on polyoma DNA and $0.56,0.44$ and 0.28 on SV 40 DNA occur at about $0.2,0.4$ and 0.8 respectively from the origin of DNA replication in the early region. The DNA segments between map positions 0.44 and 0.56 on polyoma and 0.89 and 0.98 on SV 40 contain the sequence coding for the $\mathrm{COOH}$-terminus of VP2 $\sim \mathrm{VP} 3$ and the $\mathrm{NH}_{4}$-terminus of VP1.
\end{abstract}

Polyoma virus and SV 40 have almost identical molecular biologies and genome organization,,$^{3 \sim 6)}$ but have only limited sequence homo$\operatorname{logy} .7,8)$ The genomes of both viruses are double-stranded covalently closed, circular DNAs with molecular weights of about $3.4 \times$ $10^{6}$ daltons (about 5300 nucleotide pairs). ${ }^{9,103}$ A deficiency of helical turns causes the whole molecule to twist into a compact supercoil. These twisted DNAs contain approximately $24 \sim 26$ negative superhelical turns, ${ }^{11,12}$ ) thereby the introducing localized unwinding of helical base pairs into the molecule.

S1, a single-strand-specific endonuclease from Aspergillus oryzae, ${ }^{1,13)}$ can cleave, presumably at unpaired or weakly hydrogenbonded regions, ${ }^{2,14,15)}$ both strands of superhelical DNA to generate unit length linear duplex molecules with intact single strands. This reaction proceeds by two steps: first, cleavage occurs in either one of the two strands and then, the nicked, circular DNA is cleaved on the opposite strand at or near the nicks to yield a linear molecule.

To compare tertiary DNA structure between both viruses, an attempt has been made to map the S1-cleavage sites on the genomes. Beard et al. found using electronmicroscopic analysis that SV 40 DNA is cleaved once, most often within either one of the two regions, 0.15 to 0.25 and 0.45 to 0.55 fractional lengths clockwise from the EcoRI endonucleasecleavage site. ${ }^{2}$ Germond et al., reported that polyoma DNA was also cleaved to linear duplexes by $\mathrm{S} 1$ nuclease, but the exact cleavage sites are still unknown. ${ }^{14)}$ In these experiments 
the $S 1$ reaction was performed in the presence of $\mathrm{Zn}^{2+}$ the well known activator of the enzyme. ${ }^{13}$ I have repeated these experiments using $\mathrm{Mn}^{2+}$ in place of $\mathrm{Zn}^{2+}$ and found that the enzyme is more restrictive under these conditions; $\mathrm{S} 1$ in $\mathrm{Mn}^{2+}$ cleaves DNA at defined sites yielding discrete DNA bands in agarose gel electrophoresis. Therefore I have reconstructed the map of the S1-cleavage sites of SV 40 and polyoma superhelical DNAs under these conditions. The results show that SV 40 and polyoma DNAs contain analogous S1cleavage sites suggesting possible common functional requirements.

\section{MATERIALS AND METHODS}

Substrate DNAs. Polyoma DNA (from large plaque strain ${ }^{18 j}$ ) was obtained from virus infected mouse $3 \mathrm{~T} 6$ cells as described previously. ${ }^{17)}$ SV 40 DNA was prepared from a plaque purified isolate of strain 777 and was a generous gift from Dr. K. Oda, The Institute of Medical Science, The University of Tokyo. Tritiumlabeled coliphage T7 DNA (specific activity $5 \times 10^{4}$ $\mathrm{cpm} / \mu \mathrm{g}$ ) was prepared according to the procedure reported previously. ${ }^{18)}$

Enzymes and reactions. S1 nuclease provided by Kaken Chem. Co. was further purified with SPSephadex according to the procedure of Vogt. ${ }^{13)}$ This preparation showed a single band in sodium dodecyl sulfate-polyacrylamide gel electrophoresis. Eco RI endonuclease prepared according to Green $e t$ al. ${ }^{18)}$ was a gift from Dr. T. Tanaka, Mitsubishi Kasei Institute for Life Science. Bam NI endonuclease ${ }^{20)}$ (isoschizomer to Bam HI) was provided by Dr. T. Shibata in our laboratory. $B c e 170$ endonuclease $^{21}$ (isoschizomer to $P_{s t} \mathrm{I}$ ) was provided by Dr. E. Hayase in our laboratory. Hae II, Hind III, Hpa II, Bgl I and Taq I endonucleases were purchased from Bethesda Research Laboratories, Inc. $\mathrm{Hga}$ I endonuclease was prepared according to the Takanami's procedure. ${ }^{22}$ )

The digestions were as follows: (1) S1 nuclease-DNA $(0.1 \mathrm{\mu g})$ was incubated for $30 \mathrm{~min}$ at $37^{\circ} \mathrm{C}$ with indicated amounts of the enzyme (dialyzed against 50\% glycerol) in $10 \mu$ buffer ( $30 \mathrm{~mm}$ sodiun acetate buffer (pH 5.0), $2 \mathrm{~mm}$ divalent metal, $60 \mathrm{mM} \mathrm{NaCl}$ and $5 \%$ glycerol), unless indicated otherwise. One unit of S1 activity converts $50 \%$ of heat-denatured $\left({ }^{3} \mathrm{H}\right)$-labeled T7 DNA to acid-soluble form in this condition except no addition of the metals. For sequential digestion with restriction endonuclease, S1-digested DNA was extracted with an equal volume of phenol saturated with TEN buffer (10 mM Tris- $\mathrm{HCl}(\mathrm{pH} 7.5), 1 \mathrm{~mm}$
EDTA and $10 \mathrm{~mm} \mathrm{NaCl}$ ), then $5 \mathrm{M} \mathrm{NaCl}$ was added to the aqueous layer to give a final concentration of $1 \mathrm{M}$. After treatment with ether, the DNA was precipitated with two volume of ethanol, centrifuged, and then dissolved in TEN buffer and digested further with restriction endonuclease. (2) Eco RI-0.5 $\mu \mathrm{g}$ DNA was digested for $60 \mathrm{~min}$ at $37^{\circ} \mathrm{C}$ in $25 \mu \mathrm{l}$ of buffer $(100 \mathrm{~mm}$ Tris- $\mathrm{HCl}$ (pH 7.5) and $10 \mathrm{mM} \mathrm{MgCl}$ ). (3) Bam NI and/ or Bce 170- $0.5 \mu \mathrm{g}$ DNA was digested for $2 \mathrm{hr}$ at $37^{\circ} \mathrm{C}$ with each enzyme in $25 \mu 1$ of buffer ( $50 \mathrm{mM}$ Tris-HCl (pH 7.5), $10 \mathrm{mM} \mathrm{MgCl}_{2}$ and $10 \mathrm{~mm} \beta$-mercaptoethanol). (4) Hae II, Hpa II, Bgl I and Hga I- $0.5 \mu \mathrm{g}$ DNA was digested for $2 \mathrm{hr}$ at $37^{\circ} \mathrm{C}$ with each enzyme in $25 \mu \mathrm{l}$ of buffer (20 mM Tris- $\mathrm{HCl}(\mathrm{pH} 7.5), 10 \mathrm{mM} \mathrm{MgCl} 2$ and $7 \mathrm{~mm} \beta$-mercaptoethanol). (5) Hind III $-0.5 \mu \mathrm{g}$ DNA was digested for $60 \mathrm{~min}$ at $37^{\circ} \mathrm{C}$ in $25 \mu \mathrm{l}$ of buffer (20 mM Tris- $\mathrm{HCl}$ (pH 7.5), $60 \mathrm{mM} \mathrm{NaCl}, 6 \mathrm{mM} \mathrm{MgCl}$ and $1 \mathrm{~mm}$ dithiothreitol). (6) Taq I-0.5 $\mu \mathrm{g} \mathrm{DNA}$ was digested for $60 \mathrm{~min}$ at $50^{\circ} \mathrm{C}$ in $25 \mu 1$ of buffer $(10 \mathrm{~mm}$ Tris- $\mathrm{HCl}(\mathrm{pH} 8.4), 6 \mathrm{mM} \mathrm{MgCl}_{2}$ and $6 \mathrm{~mm} \beta$-mercaptoethanol). (7) For sequential digestion with Eco RI, the first reaction buffer was adjusted to Eco RI buffer and further digestion was performed. (8) For incomplete digestion with $\mathrm{Hind}$ III and $\mathrm{Hga} \mathrm{I}, 1 / 5$ the amount of each enzyme was used under the same conditions.

Agarose gel electrophoresis. Agarose tube gels (1.2\%, $6 \mathrm{~mm}$ in diameter, $180 \mathrm{~mm}$ long) were prepared and electrophoresed in Tris-borate buffer $(89 \mathrm{~mm}$ Tris-OH, $89 \mathrm{~mm}$ boric acid and $2.5 \mathrm{~mm}$ EDTA, pH 8.228) at 150 volts for $3 \sim 4 \mathrm{hr}$. Agarose horizontal slab gels $(1.0 \%, 15 \times 20 \times 0.3 \mathrm{~cm})$ were formed and electrophoresed in Tris-acetate buffer $(50 \mathrm{~mm}$ Tris- $\mathrm{HCl}, 20 \mathrm{~mm}$ sodium acetate, $18 \mathrm{mM} \mathrm{NaCl}$ and $2 \mathrm{mM}$ EDTA, pH 8.2) at $1 \mathrm{~V} / \mathrm{cm}$ for $15 \mathrm{hr}$. The DNA bands were stained with ethidium bromide (EtBr), visualized using a short wavelength UV light, and then photographed using a orange filter (Kenko MC YA3) and Polaroid black and white Land Pack film type 665 .

\section{RESULTS}

\section{Manganese can activate $S I$ nuclease activity to almost same extent as zinc}

Figure 1 shows S1 nuclease activity on heatdenatured T7 DNA as a function of various divalent metals and enzyme concentrations. $\mathrm{Mn}^{2+}$ stimulates S1 nuclease action to almost the same extent as does $\mathrm{Zn}^{2+}$ the well established activator." Activation of the enzyme by these metals was more notable at low enzyme concentrations. As already reported by Ando, ${ }^{1} \mathrm{Ca}^{2+}$ and $\mathrm{Mg}^{2+}$ did not stimulate $\mathrm{S} 1$ nuclease activity. 


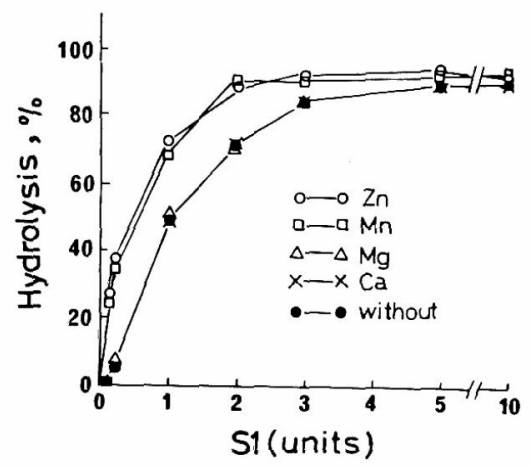

FIG. 1. S1 Nuclease Activity on Single-stranded DNA Under the Presence of Various Divalent Metals.

Tritium-labeled T7 DNA $(0.1 \mu \mathrm{g}, 5,000 \mathrm{cpm})$ was digested with indicated amounts of $\mathrm{S} 1$ using conditions described in Materials and Methods. After the reaction, $30 \mu$ l of buffer $(0.05 \mathrm{M}$ Tris- $\mathrm{HCl}(\mathrm{pH} 7.5), 0.1 \mathrm{M}$ $\mathrm{NaCl}, 0.04 \mathrm{M}$ EDTA), $10 \mu$ of salmon sperm DNA $(2.5 \mathrm{mg} / \mathrm{ml})$ and $50 \mu \mathrm{l}$ of $15 \%$ trichloroacetic acid were added and the radioactivity retained on the filters was determined.

Figure 2 indicates the cleavage patterns of covalently closed circular polyoma DNA by S1 as a function of enzyme concentration in the presence of $\mathrm{Zn}^{2+}$ and/or $\mathrm{Mn}^{2+}$ ions. The efficiency of conversion of a superhelical DNA to a unit length linear form in the presence of $\mathrm{Mn}^{2+}$ was almost the same as $\mathrm{Zn}^{2+}$ and was proportional to the concentration of enzyme used. With 5 units of $\mathrm{S} 1$, about $80 \%$ of the polyoma DNA $(0.1 \mu \mathrm{g})$ was converted to the linear form in the presence of both metals with only slight production $(\sim 5 \%)$ of fragments smaller than the unit length linear DNA. Without the metal ions or with $\mathrm{Mg}^{2+}$ and/or $\mathrm{Ca},{ }^{2+}$ the conversion of superhelical polyoma DNA to a linear form was poor(the conversion to a open circular form was complete).

Sl nuclease in the presence of manganese cleaves Polyoma DNA at specific locations

Beard et al. have already reported that S1 nuclease cleaves SV 40 DNA once within two localized regions. ${ }^{2}$ These regions were mapped using electronmicroscopy to size the DNA fragments produced by EcoRI and HpaII endonuclease-digestions of the Sl-generated unit length linear DNA. I have characterized the DNA fragments produced by sequential digestions with Sl nuclease $\left(\mathrm{Mn}^{2+}\right)$ and restriction endonucleases using agarose gel electrophoresis. Figure 3 shows two electrophoretic patterns of the polyoma DNA fragments produced by digestion of Sl-generated unit length linear DNA (also a small amount of open circular DNA) with EcoRI endonuclease. With $\mathrm{Mn}^{2+}$ as the cation in the $\mathrm{Sl}$ reaction, discrete DNA bands were evident in the gel, but with $\mathrm{Zn}^{2+}$, these bands were fainter, broader and more numerous. This means that

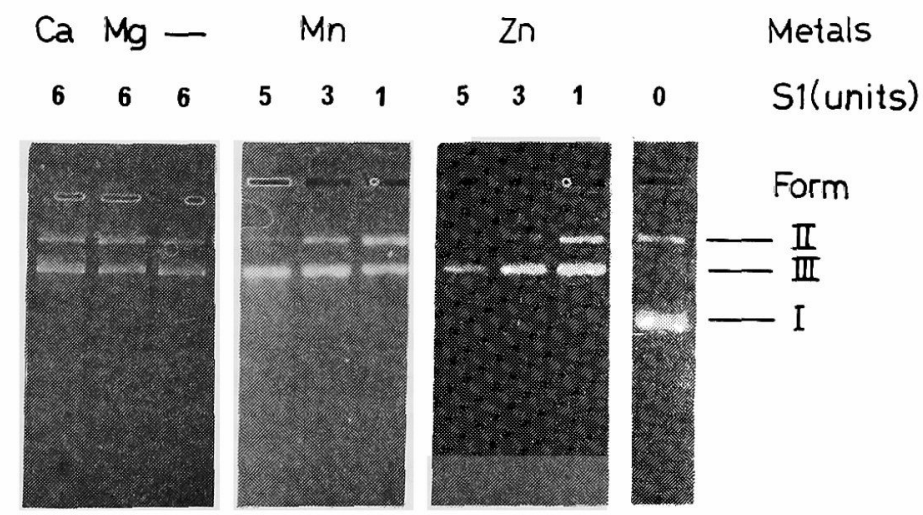

FIg. 2. Conversion of Superhelical Polyoma DNA to Unit Length Linear Form by S1 Nuclease Under the Presence of Various Divalent Metals.

Non labeled $0.1 \mu \mathrm{g}$ polyoma DNA was digested in $10 \mu 1$ of reaction buffer with the indicated amounts of S1 under conditions described in MATERIALS AND METHODS. The digests were electrophoresed in horizontal agarose slab gels as described in MATERIALs and METHODS. Form I, circular superhelical; II, open circular; III, unit length linear. 


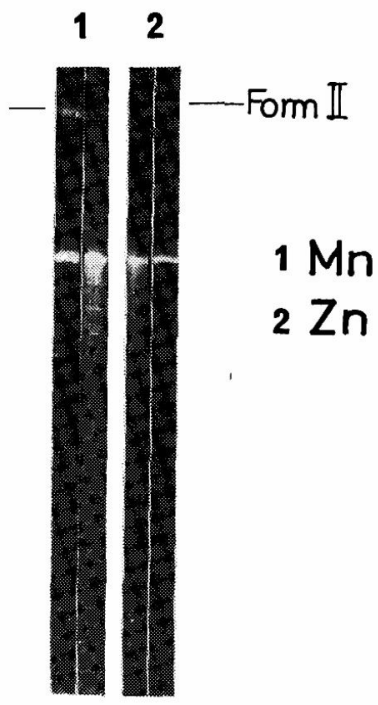

FIG. 3. Agarose Gel Electrophoretic Patterns of DNA Fragments Produced by Sequential Digestion of S1 Nuclease $\left(\mathrm{Mn}^{2+}\right.$ or $\left.\mathrm{Zn}^{2+}\right)$-Generated Unit Length Linear DNA with Eco RI Restriction Endonuclease.

$5 \mu \mathrm{g}$ polyoma DNA was digested in $500 \mu \mathrm{l}$ of reaction buffer with 250 units S1 as described in MATERIALS and METhods. S1 digestion was performed with $\mathrm{Mn}^{2+}$ (track 1) and/or $\mathrm{Zn}^{2+}$ (track 2). After recovery of the DNA as described in MATERIALS AND METHODS, $0.5 \mu \mathrm{g}$ aliquot of the S1-generated unit length linear DNAs containing slight amount of open circular DNA was digested with Eco RI endonuclease. The Eco RI endonuclease-digest was electrophoresed in agarose tube gels as described in Materials and Methods. The outer tracks are the S1 nuclease-digests without subsequent Eco RI digestion.

the length distribution of the fragments by the EcoRI nuclease-digestion is large. Since Sl nuclease is almost equally active on singlestranded DNA with $\mathrm{Mn}^{2+}$ and $\mathrm{Zn}^{2+}$, it is likely that the cleavage of polyoma DNA within the unpaired regions occurs more specifically with $\mathrm{Mn}^{2+}$ than $\mathrm{Zn}^{2+}$.

\section{Sl nuclease cleaves Polyoma DNA at seven speci-} fic sites

Mapping of the polyoma DNA sites cleaved by $\mathrm{Sl}$ nuclease in the presence of $\mathrm{Mn}^{2+}$ was performed using EcoRI and BamNI endonucleases. The results are summarized in Figure 8-A. The EcoRI endonuclease-digest of Slgenerated unit length linear polyoma DNA
12

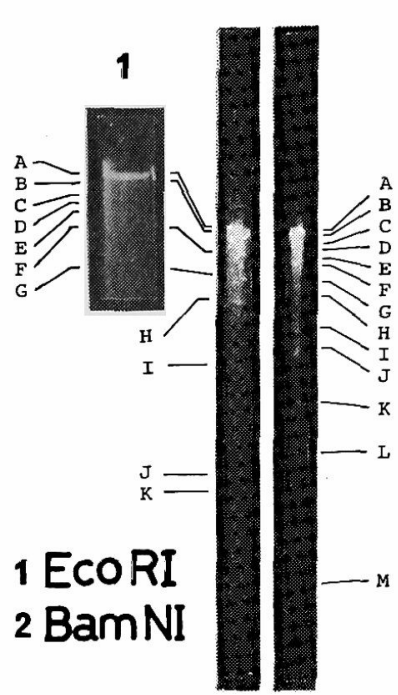

FIG. 4. Fragments of Polyoma DNA Produced after Digestion of S1 Nuclease $\left(\mathrm{Mn}^{2+}\right)$-Generated Unit Length Linear DNA with Eco RI or Bam NI Restriction Endonuclease.

$0.5 \mu \mathrm{g}$ each $\mathrm{S} 1$ nuclease-generated linear DNA (prepared as described in Fig. 3) was digested with Eco RI or Bam NI endonuclease. Each digest was electrophoresed at same time in agarose gel as described in MAterials and Methods.

(containing a slight amount of partial product, open circular DNA) yielded eleven discrete DNA bands on gel electrophoresis (Eco-A to $E c o-\mathrm{K})$ as shown in Fig. 4-1. There is also a background smear of DNA because the polyoma DNA preparation contained some randomly nicked, open circular DNA (see Fig. 2) which generate a circularly permuted set of linear DNAs that are then cleaved by the EcoRI endonuclease. As a consequence, the background in the gel is relatively high compared with that of typical restriction endonuclease-digest. Table I summarizes the sizes of these fragments, expressed in polyoma DNA fractional lengths, which were deduced from their electrophoretic mobilities using molecular length standards (see Fig. 5).

Grouped in pairs $(E c o-\mathrm{D}(0.82)+E c o-\mathrm{K}$ $(0.19) ; \quad$ Eco-E $(0.79)+E c o-J \quad(0.21) ; \quad E c o-F$ $(0.70)+E c o-\mathrm{I} \quad(0.30) ; \quad E c o-\mathrm{G} \quad(0.56)+E c o-\mathrm{H}$ $(0.44))$ the fragments add up to polyoma unit length. The pairs to Eco-B $(0.91 \sim 0.92)$ and 


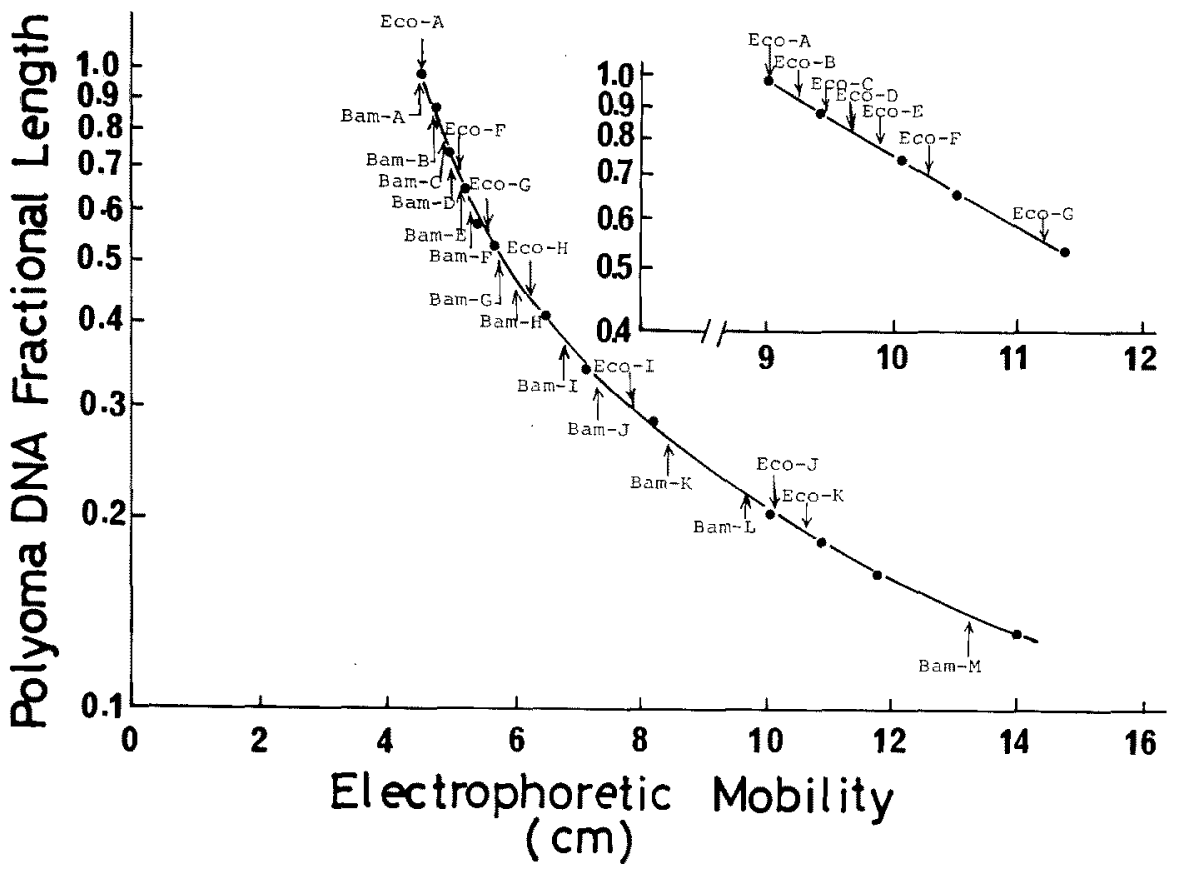

Fig. 5. A Plot of the Electrophoretic Mobility as a Function of the Logarithm of the Molecular Lengths of Polyoma DNA Fragments.

DNA fragments obtained by sequential digestion with $\mathrm{S} 1$ nuclease and $E c o$ RI or Bam NI endonuclease were at same time electrophoresed in parallel with the molecular length standards produced by cleavage with several restriction endonucleases; full length linear polyoma DNA produced by Eco RI cleavage, ${ }^{24}$ six fragments $(0.89,0.75,0.66,0.54,0.21$ and 0.13$)$ produced by $\mathrm{Hga}$ I-limit and/or incomplete cleavage, $\left.{ }^{17}\right)$ two fragments $(0.58$ and 0.42$)$ generated by sequential digestion with $B a m \mathrm{NI}^{4)}$ and $E c o \mathrm{RI}^{24)}$ and four fragments $(0.345,0.29,0.185$, and 0.165$)$ produced by $B c e 170.4,21)$ The analysis of molecular lengths of the fragments (Eco-A to Eco-G) was done separately.

Eco-C (0.89) fragments are not detectable in this gel. The production of unit length linear DNA $(E c o-A)$ is due to digestion of open circular DNA. It is unlikely that one of the SI nuclease-cleavage sites is located at or close to the EcoRI site ${ }^{24}$ ) because no fragments of about 0.58 and 0.42 fractional lengths were produced by digestion of Sl-generated unit length linear DNA with BamNI whose single cleavage site is located at 0.58 map unit on DNA*' (see Fig. 4-2 and Table I).

To map the cleavage sites, the linear DNA was digested with Bam NI endonuclease (see Fig. 4-2). Table I represents the "expected" fragment lengths assuming the Sl-cleavage occurred at seven sites concluded in Fig. 8-A. The 0.79 and 0.21 fractional length fragments produced by $E c o$ RI digestion indi- cated that SI nuclease cleaved polyoma DNA at either 0.21 or 0.79 map position or at both. If $\mathrm{Sl}$ cleaved the DNA at map position 0.21 , $B a m$ NI would generate two fragments of 0.37 and 0.63 fractional length; on the other hand, if S1 cleavage occurred at map position 0.79 , BamNI should produce two fragments of 0.21 and 0.79 fractional length. Experimentally only the 0.37 and 0.62 fragments were produced (Fig. 4-2 and Table I) indicating that one of SI nuclease-cleavage sites is located at map position 0.21 on the DNA. The other cleavage sites at map position $0.11,0.30,0.44,0.82$ and 0.92 were determined in the same way. The cleavage site at 0.56 map unit was determined as follows: The production of corresponding 0.98 and 0.02 fractional length fragments (Bam NI single cleavage site occurs at 0.58 map unit) 
Table I. Molecular Lengths of Fragments Produced in Sequential Digests of

Polyoma DNA with SI Nuclease and Eco RI OR Bam NI ENDONUClEASE

Molecular lengths of fragments were deduced from the plot shown in Fig. 5.

\begin{tabular}{|c|c|c|c|c|}
\hline \multicolumn{2}{|c|}{ Eco RI digest } & \multicolumn{3}{|c|}{ Bam NI digest } \\
\hline \multirow{2}{*}{ Fragment } & \multirow{2}{*}{$\begin{array}{l}\text { Polyoma } \\
\text { fractional } \\
\text { length } \\
\text { (observed) }\end{array}$} & \multirow[b]{2}{*}{ Fragment } & \multicolumn{2}{|c|}{$\begin{array}{c}\text { Polyoma } \\
\text { fractional length }\end{array}$} \\
\hline & & & $\begin{array}{l}\text { fractional } \\
\text { Ex- } \\
\text { pected }^{a}\end{array}$ & $\begin{array}{l}\text { length } \\
\text { Ob- } \\
\text { served }\end{array}$ \\
\hline Eco-A & 1.00 & Bam-A & $1.00+0.98$ & $1.00^{6}$ \\
\hline Eco-B & $0.91 \sim 0.92$ & Bam-B & 0.87 & 0.865 \\
\hline$E c o-\mathrm{C}$ & 0.89 & Bam-C & 0.76 & 0.765 \\
\hline Eco-D & 0.82 & $B a m-\mathrm{D}$ & 0.72 & 0.73 \\
\hline Eco-E & 0.79 & $B a m-E$ & 0.67 & 0.66 \\
\hline Eco-F & 0.70 & Bam-F & 0.63 & 0.62 \\
\hline Eco-G & 0.56 & Bam-G & 0.53 & 0.53 \\
\hline Eco-H & 0.44 & Bam-H & 0.47 & 0.47 \\
\hline Eco-I & 0.30 & $B a m-\mathbf{I}$ & 0.37 & 0.37 \\
\hline$E c o-J$ & 0.21 & Bam-J & 0.34 & 0.33 \\
\hline \multirow[t]{4}{*}{$E_{C O}-\mathrm{K}$} & 0.19 & $B a m-\mathbf{K}$ & 0.28 & 0.28 \\
\hline & & Bam-L & 0.24 & 0.235 \\
\hline & & Bam-M & 0.13 & 0.135 \\
\hline & & $B a m-\mathrm{N}$ & 0.02 & $-^{c}$ \\
\hline
\end{tabular}

a "Expected" in Bam NI endonuclease-digest are calculated fractional lengths assuming the S1 nuclease-cleavage occurred at seven sites shown in Fig. 8-A.

$b$ Bam-A band contains both unit length linear DNA generated by digestion of open circular DNA (partial product in S1 nuclease reaction) with Bam NI endonuclease and the fragment of 0.98 fractional length generated by digestion of unit length linear DNA which was produced by cutting of the DNA with S1 nuclease at 0.56 map unit, with Bam NI endonuclease (it's single cleavage site is located at 0.58 map unit. ${ }^{4}$

c Bam-N band run off from the gel (see Fig. 4-2).

could not be detected in the gel of Fig. 4-2. So, the S1 nuclease-generated linear DNA was digested with HaeII endonuclease (it's cleavage site occurs at 0.73 map unit ${ }^{4}$; in this way, two fragments 0.83 and 0.17 fractional lengths were produced. In Fig. 4-2, the 0.53 and 0.47 Bam NI fragments were relatively faint indicating that SI nuclease-cleavage at map position 0.11 is infrequent.

\section{Sl nuclease cleaves SV $40 \mathrm{DNA}$ at eight specific sites}

Beard et al., have already reported that $\mathrm{SI}$ nuclease $\left(\mathrm{Zn}^{2+}\right)$ cleaves SV 40 DNA once with-
Table II. Molecular Lengths of Fragments Produced in Sequential Digests of SV 40 DNA WITH SI NuClease AND Eco RI OR Bam NI ENDONUCLEASE

Molecular lengths of fragments were deduced from the plots shown in Fig. 7.

\begin{tabular}{|c|c|c|c|c|}
\hline \multicolumn{2}{|c|}{ Eco RI digest } & \multicolumn{3}{|c|}{ Bam NI digest } \\
\hline \multicolumn{2}{|c|}{$\begin{array}{c}\text { SV } 40 \text { fractional } \\
\text { length } \\
\text { s } \quad \text { (observed) }\end{array}$} & Fragment & \multicolumn{2}{|c|}{$\begin{array}{c}\text { SV } 40 \text { fractional } \\
\text { length } \\
\text { Expected }{ }^{c} \text { Observed }\end{array}$} \\
\hline Eco-A & $1.00^{a}$ & Bam $-\mathrm{A}$ & 1.00 & $1.00^{d}$ \\
\hline Eco-B & $0.89 \sim 0.90$ & $B a m-\mathrm{B}$ & 0.87 & 0.88 \\
\hline Eco-C & 0.85 & Bam-C & 0.83 & 0.84 \\
\hline Eco-D & 0.73 & Bam-D & $0.77+0.76$ & $0.76^{e}$ \\
\hline Eco-E & $0.61^{b}$ & $B a m-\mathrm{E}$ & 0.75 & 0.75 \\
\hline Eco-F & 0.56 & Bam-F & 0.71 & 0.70 \\
\hline Eco-G & 0.44 & Bam-G & 0.59 & 0.57 \\
\hline Eco-H & 0.39 & Bam-H & 0.41 & 0.43 \\
\hline Eco-I & 0.38 & Bam-I & 0.29 & 0.293 \\
\hline$E c o-J$ & 0.28 & Bam-J & 0.26 & 0.255 \\
\hline Eco-K & 0.15 & Bam-K & $0.23+0.24$ & $0.24^{e}$ \\
\hline \multirow[t]{2}{*}{ Eco-L } & 0.12 & Bam-L & 0.17 & 0.17 \\
\hline & & $B a m-\mathrm{M}$ & 0.13 & $-f$ \\
\hline
\end{tabular}

a Eco-A band contains both unit length linear DNA generated by digestion of open circular DNA (partial product in S1 nuclease reaction) with Eco RI endonuclease and the fragment of 0.98 fractional length generated by digestion of unit length linear DNA which was produced by cutting of the DNA with S1 nuclease at 0.98 map unit with Eco RI endonuclease (it's cleavage site occurs at $0 / 1.0$ map unit. ${ }^{43)}$

$b \quad$ Eco-E band is doublet containing two fragments of 0.62 and 0.61 fractional lengths which are pairs to Eco-I (0.38 fractional length) and Eco-H $(0.39$ fractional rength) respectively. These fragments are not separable in the gel (see Fig. 6-1).

c "Expected" in Bam NI endonuclease-digest are calculated fractional lengths assuming the S1 nuclease-cleavage occurred at eight sites shown in Fig. 8-B.

d Bam-A band contains the two sorts of unit length linear DNA generated by Bam NI endonuclease; one is the digest of open circular DNA and another is the digest of unit length linear DNA produced by cutting of the DNA with S1 nuclease at 0.15 map unit (just Bam NI-cleavage site). ${ }^{25}$ )

- Bam-D and Bam-K bands are doublets containing the fragments of 0.77 and 0.76 fractional lengths and 0.23 and 0.24 fractional lengths, respectively. Two sets of the fragments are not separable in the gel (see Fig, 6-2). These four fragments were generated after digestion of unit length linear DNA which was produced by cutting of SV 40 DNA with S1 nuclease at 0.38 or 0.39 map unit, with Bam NI endonuclease.

$f \quad B a m-M$ band is not clear in the gel shown in Fig. 6-2. 


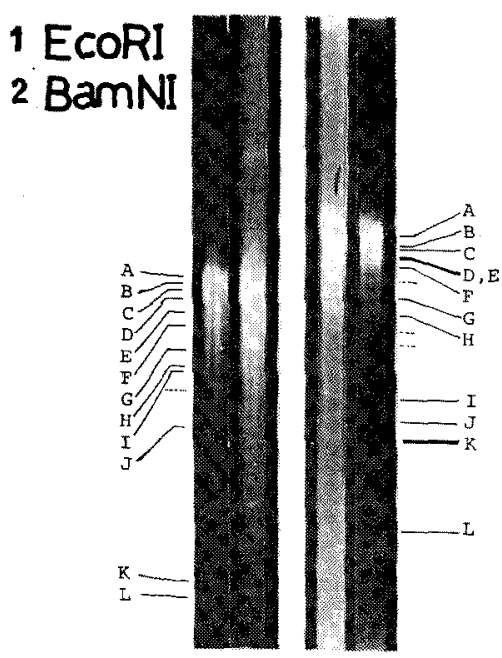

F1G. 6. Fragments of SV 40 DNA Produced after Digestion of S1 Nuclease $\left(\mathrm{Mn}^{2+}\right)$-Generated Linear DNA with Eco RI or Bam NI Restriction Endonuclease.

$0.5 \mu \mathrm{g}$ each S1 nuclease-generated unit length linear DNA containing slight amount of open circular form prepared as described with polyoma DNA was digested with Eco RI (track 1) or Bam NI (track 2) endonuclease. Each digest was electrophoresed independently in agarose gels.

in the region $0.15 \sim 0.25$ or $0.45 \sim 0.55$ map unit. $^{2}$ Here, I have mapped the cleavage sites on SV 40 DNA produced by SI nuclease in the presence of $\mathrm{Mn}^{2+}$. The results are summarized in Fig. 8-B. Figure 6-1 shows the electrophoretic pattern of the digest of the SI nuclease generated linear SV 40 DNA with $E c o$ RI endonuclease. The sizes of the twelve DNA bands (Eco-A to Eco-L), expressed in SV 40 fractional lengths (see Fig. 7), are summarized in Table II. The map locations of the Sl-cleavage sites were determined as described for polyoma. Grouped in pairs (EcoB $(0.89 \sim 0.90)+E c o-L(0.12) ; E c o-C(0.85)+$ Eco-K (0.15); Eco-D $(0.73)+E c o-\mathrm{J} \quad(0.28)$; Eco-E $(0.61)+E c o-H, \mathrm{I}(0.39,0.38) ; \quad E c o-\mathrm{F}$ $(0.56)+E c o-G(0.44))$ the fragments add up to SV 40 unit length. The band at the position of unit length linear $(E c o-A)$ is produced from the open circular DNA. The fragment of 0.98 fractional length results from S1 nucleasecleavage at 0.98 map unit based on the following data: (1) As shown in Fig. 6-2 and
Table II, a small fragment of 0.17 fractional length is formed after digestion of Sl-generated linear DNA with Bam NI (cleavage site is located at 0.15 map unit. ${ }^{25}$ ) (2) Of the two possible S1 nuclease-cleavage sites, either map location 0.98 or 0.32 , the latter can be ruled out because no band of 0.32 fractional length is formed after digestion with EcoRI (see Fig. 6-1 and Table II). (3) A new fragment of 0.25 fractional length is produced by digestion of Sl-generated linear DNA with Hpa II endonuclease (cleavage site is located at 0.73 map unit. ${ }^{23}$

To map the Sl nuclease-cleavage sites the SV 40 linear DNA was digested with BamNI (Fig. 6-2). Table II represents the "expected" fragments assuming the Sl-cleavage occurred at the eight sites shown in Fig. 8-B. The cleavage sites at map unit 0.15 and 0.28 , and 0.44 and 0.56 correspond to those reported by Beard et al. ${ }^{2)}$ The cleavage site at 0.15 map unit was confirmed by production of two fragments of 0.52 and 0.48 fractional lengths after digestion of Sl-generated linear DNA with $B g l I$ endonuclease (it's single cleavage site occurs at 0.67 map unit (Roberts, personal communication). In my experiment, additional SI-sensitive sites were located at 0.38 , 0.39 and 0.89 on the SV 40 DNA map. These were confirmed by digestion of the SI nucleasegenerated linear DNA with TaqI endonuclease $^{26)}$ (cleavage site is located at 0.56 map unit (Roberts, personal communication)). This leads to the production of fragments with fractional lengths of $0.18,0.17$ and 0.33 .

In Figs. 6-1 and -2 , there are also one or three faint DNA bands after. This indicates that there are one or two extra minor cleavage site(s) on SV 40 DNA.

\section{DISCUSSION}

In this paper, I have shown that covalently closed circular DNAs of polyoma virus and SV 40 are cleaved more specifically by SI nuclease in the presence of $\mathrm{Mn}^{2+}$ than with $\mathrm{Zn}^{2+}$ although both divalent cations are almost equally effective activators of the enzyme with 


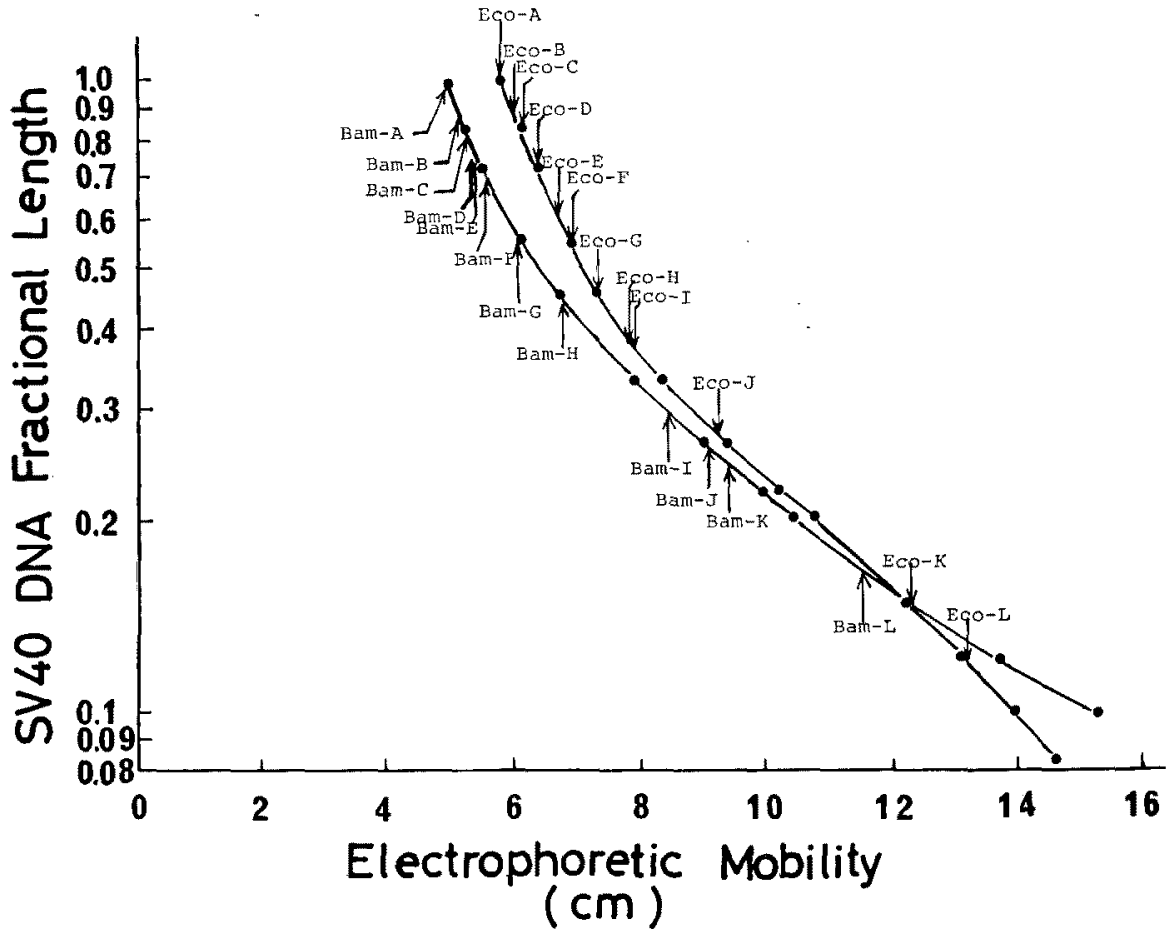

Fig. 7. Plots of the Electrophoretic Mobility as a Function of the Logarithm of the Molecular Lengths of SV 40 DNA Fragments.

DNA fragments obtained by sequential digestion with S1 nuclease and Eco RI or Bam NI endonuclease were independently electrophoresed in parallel with the molecular length standards produced by cleavage with several restriction endonucleases; full length linear DNA produced by $E c o$ RI cleavage, ${ }^{48)}$ two fragments $(0.85$ and 0.15$)$ generated by sequential digestion with $B a m \mathrm{NI}^{25)}$ and $E c o$ RI, two fragments $(0.73$ and 0.27$)$ generated by sequential digestion with $H p a \mathrm{II}^{23)}$ and Eco RI, two fragments (0.56, and 0.44$)$ obtained by sequential digestion with $T a q \mathrm{I}^{2 \theta)}$ and Eco RI and six fragments $(0.34,0.225,0.205,0.125,0.105$ and 0.085$)$ produced by limit and incomplete Hind III cleavage. ${ }^{47,48}$

single-stranded DNA. How and why $\mathrm{Mn}^{2+}$ produces this effect is not clear. $\mathrm{Mn}^{2+}$ also alters the specificity of pancreatic DNase $I^{27}$; with $\mathrm{Mg}^{2+}$, DNase I introduces random singlestrand breaks into double-stranded DNA, but with $\mathrm{Mn}^{2+}$, the enzyme also produces doublestrand scissions into the DNA.

The genomes of polyoma and SV 40 show striking similarities in the structure and genetic organization $^{3 \sim 6)}$ even though their base sequences have only limited homology; the region between 0.93 and 0.98 map unit on $\mathrm{SV}$ 40 DNA is partially homologous with the region between 0.47 and 0.52 map unit on polyoma $\mathrm{DNA}^{7)}$, the nucleotide arrangement of their origins of genome replication are similar, ${ }^{8)}$ and some sequences in early region coding tumor antigen are analogous (E. Soeda, personal communication). My experiments show that their sensitivities to SI nuclease-cleavage are also strikingly similar: (1) Both are cleaved at or close to the site at which DNA replication terminates and the $3^{r}$ ends of the early and late mRNAs (map unit 0.15 in SV 40 and 0.21 in polyoma); (2) the region in which the coding sequences for VP2/VP3 terminate and the coding sequence for VP1 begins is placed between two cleavage sites (map unit 0.89 and 0.98 on SV 40 and map unit 0.44 and 0.56 on polyoma); (3) three cleavage sites on each DNA $(0.56,0.44$ and 0.28 on SV $40,0.82,0.92$ and 0.11 on polyoma) 
A)

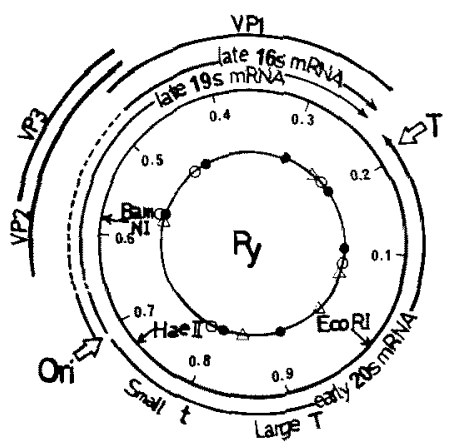

B)

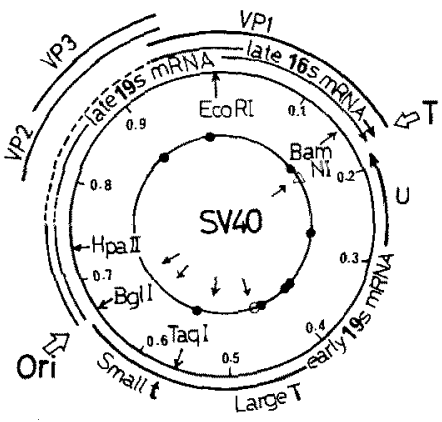

FIG. 8. Summary of S1 Nuclease-cleavage Sites on Polyoma DNA and SV 40 DNA from Point of View of Viral Genome Organization.

(A) Polyoma DNA: $\bullet$, seven S1 nuclease-cleavage sites; $O$, five preferential binding sites of T4 gene 32 protein; ${ }^{29)} \triangle$, five preferential binding sites of $E$. coli RNA polymerase. ${ }^{28)}$ Ori. and $T$. indicate the positions of origin and terminus of genome replication. ${ }^{g \sim \theta}{ }^{9}$ Restriction endonuclease ( $E c o$ RI, Bam NI and Hae $\mathrm{III}^{4}$ ) -cleavage sites are shown. The maps of mRNA and gene products are also shown, $8,4,6,34,48$ )

(B) SV 40 DNA: $\bullet$, eight S1 nuclease-cleavage sites; $O$, one strong binding site of T4 gene 32

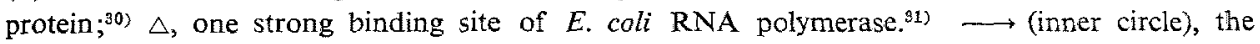
initiation sites for RNA synthesis by $E$. coli RNA polymerase. ${ }^{50}$ Ori. and T. indicate the positions of origin and terminus of genome replication..$^{3 \sim 6,43)}$ Restriction endonuclease (Eco RI, Bam NI, Hpa II, Bgl I and Taq I)-cleavage sites are shown. The maps of mRNA and gene products are also shown. ${ }^{3,4,8,85,38,43)}$

are located at around $0.2,0.4$ and 0.8 respectively the distance from the origin of DNA replication in the early regions of the two viruses.

It is known that $\mathrm{T} 4$ gene 32 protein (helix destabilizing protein) and Escherichia coli RNA polymerase bind preferentially to unpaired and/or weakly hydrogen-bonded regions on polyoma ${ }^{28,29)}$ and SV $40 \mathrm{DNAs}^{30,31)}$; these sites are also indicated in Fig. 8. Of interest is the fact that these sites occur at or near S1-cleavage sites in polyoma DNA (see Fig. 8-A) and that there is tendency in that direction in SV 40 DNA (see Fig. 8-B).

Recently, Shen and Hearst, ${ }^{32)}$ (Hearst, personal communication) and $\mathrm{Hsu}$ and Jelinek ${ }^{33)}$ have reported that SV 40 DNA contains inverted repeated regions (sequences with 2fold symmetry). The positions of inverted repeats coincide with the positions at which 3'- and 5'-ends of early and late mRNAs have been mapped. ${ }^{34 \sim 38)}$ Moreover, recombination events either within the SV 40 genome $^{39,40)}$ or between SV 40 and the adenovi- ruses to form a family of Adeno-SV 40 hybrids ${ }^{41 \sim 44}$ have frequently occurred at the position of inverted repeated sequences. ${ }^{33)}$ It is noteworthy that these inverted repeated regions exhibit nice agreement with $\mathrm{S} 1$ nucleasecleavage sites.

What the structure-function correlates between Sl nuclease sensitivity and mRNA production (e.g., processing, termination, etc.) or recombination is not clear. Whether it reflects the existence and functional requirement of cloverleaf-like folding with Sl nucleasesensitive-single-strand portions in the supercoiled DNA ${ }^{45)}$ remains to be determined.

Acknowledgments. The author gratefully acknowledge Dr. Paul Berg for critical reading of the manuscript and Dr. Tadahiko Ando for his encouragement. I also than Dr. Kin-ichiro Oda for kindly providing purified SV 40 particles, Drs. Teruo Tanaka, Takehiko Shibata and Eiji Hayase for generously supplying of the restriction enzymes, and Kaken Chem. Co. for their help during the course of the preparation of S1 nuclease.

This work was supported in part by a grant for the studies on "Biosciences" at The Institute of Physical and Chemical Research. 


\section{REFERENCES}

1) T. Ando, Biochim. Biophys. Acta, 114, 158 (1966).

2) P. Beard, J. F. Morrow and P. Berg, J. Virol., 12, 1303 (1973).

3) G. C. Fareed and D. Davoli, "Ann. Rev. Biochem.," Vol. 46, Ann. Rev. Inc., Palo Alto, California, 1977 , p. 471.

4) M. Fried and B. E. Griffin, "Adv. Cancer Res," Vol. 24, ed. by G. E. Orge and S. Weinhouse, Academic Press Inc., New Yorks, N. Y., 1977, p. 67.

5) K. Shishido, Protein Nucleic Acid Enzyme, 23, 878 (1978).

6) In abstracts of the International Symposium on Papovaviruses and Their Role in Cell Transformation and Oncogenesis, National Institutes of Health, U.S.A., 1978.

7) J. Ferguson and R. W. Davis, J. Mol. Biol., 94, 135 (1975).

8) E. Soeda, K. Kimura and K. Miura, Proc. Nall. Acad. Sci. U.S.A., 75, 162 (1978).

9) L. V. Crawford and P. H. Black, Virol., 24, 388 (1964).

10) J. Vinograd, J. Lebowitz, R. Radloff, R. Watson and P. Laipis, Proc. Natl. Acad. Sci. U.S.A., 53, 1104 (1965).

11) W. Keller, ibid., 72, 4876 (1975).

12) M. Shure, D. E. Pulleyblank and J. Vinograd, Nucleic Acid Res., 4, 1183 (1977).

13) V. M. Vogt, Elir. J. Biochem., 33, 192 (1973).

14) J.-E. Germond, V. M. Vogt and B. Hirt, Eur. J. Biochem., 43, 591 (1974).

15) K. Shishido and T. Ando, Agric. Biol. Chem., 39, 673 (1975).

16) R. Dulbecco, L. H. Hartwell and M. Vogt, Proc. Natl. Acad. Sci. U.S.A., 53, 403 (1965).

17) K. Shishido and P. Berg, J. Virol., 18, 793 (1976).

18) K. Shishido, Biochim. Biophys. Acta, 312, 708 (1973).

19) P. J. Greene, M. C. Betlach, H. M. Goodman and H. W. Boyer, "Methods Mol, Biol.," Vol. 7, ed. by R. B. Wickner, Marcel Dekker, New York, 1974, p. 87.

20) T. Shibata and T. Ando, Biochim. Biophys. Acta, 442, 184 (1976).

21) T. Shibata, S. Ikawa, C. Kim. and T. Ando, $J$. Bacteriol., 128, 473 (1976).

22) M. Takanami, "Methods Mol. Biol.," Vol. 7, ed. by R. B. Wickner, Marcel Dekker, New York, 1974, p. 113.

23) P. A. Sharp, B. Sugden and J. Sambrook, Biochemistry, 12, 3055 (1973).

24) B. E. Griffin, M. Fried and A. Cowie, Proc. Natl. Acad. Sci. U.S.A., 71, 2077 (1974).

25) C. N. Cole, T. Landers; S. P. Goff, S. ManteuilBiutlag and P. Berg, J. Virol., 24, 277 (1977).
26) S. Sato, C. A. Hutchison and J. I. Harris, Proc. Natl. Acad. Sci. U.S.A., 74, 542 (1977).

27) E. Melgar and D. A. Goldthwait, J. Biol. Chem., 243, 4409 (1968).

28) J. Monjardino and A. W. James, Nature, 255, 249 (1975).

29) B. Lescure, P. Oudet, P. Chambon and M. Yaniv, J. Mol. Biol., 108, 83 (1976).

30) J.F. Morrow and P. Berg, J.Virol., 12, 1631 (1973).

31 B. Allet, R. J. Roberts, R. F. Gesteland and R. Solem, Nature, 249, 217 (1974).

32) C.-K. Shen and J. E. Hearst, Proc. Natl. Acad. Sci. U.S.A., 74, 1363 (1977).

33) M.-T. Hsu and W. R. Jelinek, ibid., 74, 1631 (1977).

34) N. H. Acheson, Cell, 8, 1 (1976).

35) W. Fiers, R. Contreras, G. Haegeman, R. Rogiers, A. Van de Voorde, H. Van Heuverswyn, J. Van Herreweghe, G. Volckaert and M. Ysebaert, Nature, 273, 113 (1978).

36) S. Lavi and Y. Groner, Proc. Natl. Acad. Sci. U.S.A., 74, 5323 (1977).

37) E. May, J. V. Maizel and N. P. Salzman, ibid., 74, 496 (1977).

38) V. B. Reddy, B. Thimmappaya, R. Dahr, K. N. Subramanian, B. S. Zain, J. Pan, P. K. Ghosh, M. L. Celma and S. M. Weissman, Science, 200, 494 (1978).

39) G. Khoury, G. C. Fareed, K. Berry, M. A. Martin, T. N. H. Lee, and D. Nathans, J. Mol. Biol., 87, 289 (1974).

40) J. E. Mertz, J. Carbon, M. Hertzberg, R. W. Davis and P. Berg, Isolation and Characterization of Individual Clones of Simian Virus 40 Mutants containing Deletions, Duplications and Insertions in Their DNA, Cold Spring Harbor Symposium, Quant. Biol., 39, 69 (1974).

41) T. J. Kelly Jr., J. Virol., 15, 1267 (1975).

42) T. J. Kelly Jr., A. M. Lewis Jr., A. S. Levine and S. Siegal, J. Mol. Biol., 89, 113 (1974).

43) T. J. Kelly Jr. and D. Nathans, "Adv. Virus. Res.," Vol. 21, ed. by M. A. Lauffer, F. B. Bang, K. Maramorosch and K. M. Smith, Academic Press Inc., New York, N.Y., 1977, p. 86.

44) P. Lebowitz, T. J. Kelly Jr., D. Nathans, T. N. H. Lee and A. M. Lewis Jr., Proc. Natl. Acad. Sci. U.S.A., 71, 441 (1974).

45) H. M. Sobell, ibid., 69, 2483 (1972).

46) J. F. Morrow and P. Berg, ibid., 69, 3365 (1972),

47) K. J. Danna, G. H. Sack and D. Nathans, $J$. Mol. Biol., 78, 363 (1973).

48) R. Yang, K. Danna, A. Van de Voorde and W. Fiers, Virol., 68, 260 (1975).

49) R. Kamen and H. Shure, Cell., 7, 361 (1976).

50) P. Lebowitz, R. Stern, P. K. Ghosh and S. M. Weissman, J. Virol., 22, 430 (1977). 